\title{
When the Shepherd Rejoins the Flock: Returning to the Department after Serving as Chair
}

Bill Bernhard, University of Illinois at Urbana-Champaign

Mona Lyne, University of Missouri, Kansas City

ABSTRACT Reassuming the role of a "regular" faculty member after serving as department chair presents a common set of challenges that often are overlooked and underappreciated in the discipline. To provide former chairs with guideposts for navigating this pivotal moment in their career, we offer a few thoughts on what our experience suggests are the keys to a successful transition. Among the issues to consider are time and space to regroup, mining what you have learned as chair to revamp research and teaching, careful management of your new social status in the department, and envisioning how you can lead without holding a formal position.

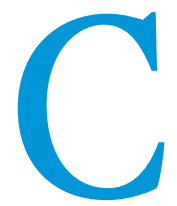

ongratulations on completing the most difficult job in the university! Many feel great relief to move out of the role of chair and return to full-time research and teaching. There is a sense of freedom that comes with a reduction in responsibility. At the same time, reassuming the role of a "regular" faculty member presents a common set of challenges that often are overlooked and underappreciated in the discipline. Former chairs returning to their department possess few guideposts for navigating this pivotal moment in their career. It can be difficult to relinquish control and let go of the outsized ability to shape outcomes in and for the department. The chair role also provided an identity within the institution-as department chair, colleagues, administrators, students, and alums actively sought your counsel. After stepping down, it may seem that your opinion is less valued, which can be difficult to accept. Alternatively, some faculty/staff may continue to perceive/treat you as their mentor/leader, which poses challenges of its own.

This article offers a few thoughts on what our experience suggests are the keys to a successful transition. Among the issues to consider are time and space to regroup, mining what you have learned as chair to revamp research and teaching, careful management of your new social status in the department, and envisioning how you can lead without holding a formal position.

\section{REBUILDING RESEARCH AND TEACHING}

Most chairs are aware of the need to rebuild their research and teaching. Indeed, they are looking forward to it. Chairs necessarily

Bill Bernhard is vice provost for academic affairs at the University of Illinois at UrbanaChampaign. He can be reached at bernhard@illinois.edu.

Mona Lyne id is associate professor of political science at the University of Missouri, Kansas City. She can be reached at lynem@umkc.edu. put research on the "back burner" and often have a reduced teaching load. You will need time and space to reconstitute these activities. If your institution permits it, negotiating a semester or year of leave to restart research and revise teaching can help. If a leave is not possible, some physical distance between you and the department can be beneficial in guarding your time and allowing everyone to adjust to new roles. A request for specific research space or taking advantage of workspace away from the office (e.g., home, library, or coffee shop) as much as possible can achieve some of the same effect. This also will help faculty get used to reaching out to the new chair for department-related concerns and questions.

This is also a time for fresh starts: investing in a new research project, a new course prep, or a new teaching mode (e.g., online teaching) can provide a stimulating challenge. Use the institutional knowledge you accrued as chair to take advantage of campus resources that support research and teaching. As chair, you likely built a network of contacts outside of your department. Engage those contacts to develop new interdisciplinary research projects or student opportunities. Leverage the knowledge and experience gained during your stint as chair to push your research and teaching in novel directions.

Finally, set reasonable expectations for yourself. Identify doable tasks rather than tackling the major unfinished items you want to accomplish. It will take significant time-likely a full year-to rebuild momentum. Be patient.

\section{BUILDING A RELATIONSHIP WITH THE NEW CHAIR}

Whereas returning to one's old role as a full-time researcher and teacher will take some adjustment, a smooth return to one's old social position in the department requires finesse and 
careful judgment. Among the more important aspects of this transition is the relationship with the new chair. It is worth trying to remember how you felt as you started in the position and how you wanted to be treated by your predecessor. Was the previous chair overbearing and unable to give up control or absent, of these concerns, to keep that information strictly private, and to compartmentalize any personal knowledge you may possess by virtue of having served as chair.

As chair, you likely made decisions that may have angered some colleagues, precipitating difficult interactions. Do not

\section{This is also a time for fresh starts: investing in a new research project, a new course prep, or a new teaching mode (e.g., online teaching) can provide a stimulating challenge.}

unhelpful, or uncommunicative? Ideally, one treads the fine line to be supportive yet not intrusive. It will be important to speak directly with the new chair about how you both view your role as former chair. A direct statement to the new chair (e.g., "I will help you, but you need to ask. I don't want to assume that you need or want my help") can go a long way toward getting the relationship off on the right foot. It also can help the new chair if, on occasion, you commiserate with what she or he is experiencing. Depending on career trajectories and relationships, it may be possible to take on a mentoring role with the new chair-but always with carefully drawn boundaries and a clear understanding of roles between you.

It is important to give the new chair space to make mistakes and to respect the new chair's priorities and decisions. Be selective about when you offer advice; always be sure to provide it privately; and be prepared to accept the chair's decisions, even if they do not align with your advice. At the same time, when you agree with decisions-particularly when they are difficult or controversialyou can play a valuable role by publicly supporting the decision and, if appropriate, by providing additional rationale based on your experience.

The new chair may overturn some of your decisions made as chair. Try not to take this personally-it is natural for a new chair to assume office with an agenda to change something about the department. It also is possible that as the new chair learns more about the situation, he or she will come to appreciate the logic of your original decisions.

It is important that you quickly redirect faculty to the new chair if they attempt to treat you as the decision maker. Nothing will undermine the relationship more quickly than actions-even if innocentthat encroach on or undermine the position of the new chair.

\section{REBUILDING TRUST WITH COLLEAGUES}

This leads to the second delicate transition in social roles between you and your colleagues. Do not expect your relationship with your colleagues to return to what it was before you served expect anyone to apologize to you. At the same time, you do not need to apologize-the decisions you made were your responsibility in your role. Most important, do not prolong or revisit any disputes after assuming your new role; this is highly unlikely to be productive. Similarly, there may be those faculty colleagues who continue to have an "axe to grind" with you. If confronted, maintain your composure. You may even remind your colleague that time has passed and a new leader has assumed the role. Good leadership and a smooth transition mean carrying no grudges both during service as chair and after.

With your colleagues, it will take time to restore trust. You will need to demonstrate to them that what happened while you were chair is in the past and that you can interact with them as an equal again. Working together on a project with uncontroversial goals (e.g., helping students succeed) is a good place to begin to reestablish relationships.

Finally, do not expect thanks from colleagues, even from those who think you did a good job. Unfortunately, most of what administrators do is in the "background" and often can be taken for granted. Falling into the trap of feeling your service was underappreciated can be destructive to your career. Move on to other projects and activities.

\section{LEADING WITHOUT CHAIRING}

Although you no longer hold the formal position of chair, this does not mean that you are no longer a leader. As chair, you gained insights and experiences that differentiate you from those who have not served in a leadership position. Use that knowledge to contribute to your department's success.

You have a broader perspective on the department's role in the university and how it connects with the overall mission of the university. You are familiar with the Dean's Office and how it makes decisions. Consequently, you can help to frame departmental programs and requests in a way that makes it more likely for those initiatives to succeed with the upper administration.

\section{With your colleagues, it will take time to restore trust. You will need to demonstrate to them that what happened while you were chair is in the past and that you can interact with them as an equal again.}

as chair. As chair, you were privy to information about, had interactions with, and observed behavior of your colleagues that you simply cannot erase from your memory. Colleagues may have shared confidences that they now might find embarrassing, making them feel vulnerable around you. It is important to be aware
As chair, you learned about the importance of process and rules as well as the value of transparency and consistency, and you have a more informed view of what is and is not feasible. That knowledge can help to inform how the department organizes its business. 
You know firsthand that chairs and other administrators make mistakes and that when faculty have patience with their leaders, those leaders will be able to do a better job. You can provide this perspective for those who have not seen the university from the administrative side.

Finally, once you have had some rest, you can consider volunteering to take on a department initiative (e.g., building an online program or developing a study-abroad program), particularly if it dovetails with a need within the department/college/university. You may even contemplate taking on other formal roles within the university.
Leaving the position of chair is obviously easier than entering it, but this transition presents challenges and potential pitfalls. We wish you all the best as you navigate your return to the role of a "regular" faculty member within your department.

\section{ACKNOWLEDGMENTS}

We thank Steven Abel, John Coleman, David Irwin, David Leblang, Anna-Marie Marshall, Amy Santos, Jamelle Sharpe, Charles Shipan, and Tracy Sulkin for helpful comments and suggestions. 